\title{
A NEW SPECIES OF STENANONA (ANNONACEAE) ENDEMIC TO ChIAPAS, MEXICO
}

\author{
Andres Ernesto Ortiz-Rodriguez", 5 , George E. Schatz², Yuyini Licona-Vera and \\ Eduardo Ruiz-SanCheZ ${ }^{4}$ \\ 'Instituto de Ecología, A.C., Red de Biodiversidad y Sistemática, Xalapa, Veracruz, Mexico \\ ${ }^{2}$ Missouri Botanical Garden, St. Louis, Missouri, USA \\ ${ }^{3}$ Instituto de Ecología, A.C., Red de Biología Evolutiva, Xalapa, Veracruz, Mexico \\ ${ }^{4}$ Instituto de Ecología, A.C., Centro Regional de Bajío, Red de Biodiversidad y Sistemática, \\ Pátzcuaro, Michoacán, Mexico \\ ${ }^{5}$ Corresponding author: ortizrodriguez.ae@gmail.com
}

\begin{abstract}
A new species endemic to Chiapas, Mexico, Stenanona migueliana (Annonaceae), is described and illustrated. The new species has affinity with $S$. stenopetala, from which it differs in the length of the floral pedicel, size of the sepals, arrangement of the ovules, and surface texture of the fruit. A key to the Mexican species of Stenanona is presented.
\end{abstract}

Keywords: Berriozábal, conservation, Neotropics, taxonomy, tropical moist forests.

Resumen: Se describe e ilustra Stenanona migueliana (Annonaceae), una especie endémica del estado de Chiapas, México. La nueva especie presenta afinidad con S. stenopetala, de la cual difiere en el largo del pedicelo floral, el tamaño de los sépalos, la disposición de los óvulos y la textura de la superficie del fruto. Se incluye una clave para las especies mexicanas del género Stenanona.

Palabras clave: Berriozábal, bosque tropical húmedo, conservación, Neotropicos, taxonomía.

$S$ enanona Standl., is a Neotropical genus of dwarf to small trees that comprises 14 described species, geographically distributed from southern Mexico to southern Colombia at elevations ranging from 0 to $1,250 \mathrm{~m}$. Species of Stenanona inhabit tropical, moist, evergreen, and montane rain forests (Schatz and Maas, 2010).

The new subfamilial and tribal classification of Annonaceae places Stenanona within subfamily Malmeoideae, tribe Miliuseae (Chatrou et al., 2012). In the most recent molecular phylogenetic analysis of Annonaceae (Chatrou et al., 2012), based on eight plastid markers, two Stenanona species are shown as monophyletic and sister to a paraphyletic Desmopsis, a genus also centered in Mesoamerica. The divergence of Stenanona and Desmopsis based on Penalized Likelihood (PL) was estimated to be a mean age of $35 \mathrm{Ma}$ $(\mathrm{SD}=7 \mathrm{Ma})$, whereas the mean age estimated with BEAST was $15 \mathrm{Ma}(\mathrm{HPD} 95 \%=10-20 \mathrm{Ma})$, indicating a diversification between Mid-Eocene and Mid-Miocene (Pirie and Doyle, 2012).
In Mexico (Chiapas, Oaxaca, Tabasco, and Veracruz), have been recorded seven of the 15 species of Stenano$n a$, six of which are endemic to Mexico, with only one species, Stenanona stenopetala (Donn.Sm.) G.E.Schatz, extending its range to Guatemala and Belize (Schatz and Maas, 2010). The petal morphology of Stenanona, in combination with the pink to blood red color of the flower, is suggestive of a fly pollination syndrome (Schatz, 1987). This character could be related to the high rate of diversification of this genus (Couvreur et al., 2011; Erkens et al., 2012).

During the course of a series of botanical explorations in a protected area in the state of Chiapas, Mexico, which is in the process of being enacted as a reserve, we collected a species of Stenanona with a unique combination of leaf, flower, and fruit characteristics that permitted us to conclude that it is new to science. A description of the new species, with an accompanying illustration and photos, and a key to the Mexican species of Stenanona, are presented. 


\section{Key to the species of Stenanona in Mexico.}

1. Inflorescences borne on flagella running over the surface of the ground (flagelliflorous); petals $<15 \mathrm{~mm}$ long, lacking a long drawn-out apex (Oaxaca and Veracruz) ..S. flagelliflora T.Wendt \& G.E.Schatz 1. Inflorescences borne among leaves, on horizontal branches, or on the main vertical trunk; petals $>20 \mathrm{~mm}$ long, with a long, drawn-out apex

2. Inner and outer petals equal to subequal, linear to lineartriangular; plants not clonal; ovules $>2$

3. Flowers 4-merous; sepals basally connate; lamina glabrous below; pedicels 8-12 mm (Chiapas and Tabasco).................S. cauliflora (J.W.Walker) G.E.Schatz 3. Flowers usually 3-merous; sepals free; lamina with erect to appressed hairs on the lower side; pedicels 9$40 \mathrm{~mm}$

4. Pedicel 9-23 mm; sepals 2-3 mm long; ovules uniseriate; surface of monocarps smooth, minutely verrucose (Tabasco, Chiapas to Belize)

S. stenopetala (Donn.Sm.) G.E.Schatz

4. Pedicel 20-40 mm; sepals 3-6 mm long; ovules biseriate; surface of monocarps strongly tuberculate (Chiapas) ....... S. migueliana Ortíz-Rodríguez \& G.E.Schatz 2. Inner and outer petals unequal, the outer petals linear to narrowly triangular, the inner ones narrowly ovate-triangular; plants clonal, spreading vegetatively by underground stolons (unknown for S. monticola Maas \& G.E.Schatz); ovule one

5. Pedicels 3-7 mm long; petals 5-11 mm long (Oaxaca, Veracruz) ............ S. wendtii G.E.Schatz \& Maas 5. Pedicels 9-21 mm long; petals 10-44 mm long

6. Petals 23-24 mm long; sepals c. $3 \mathrm{~mm}$ long; plants without minute, lens-like warts (Chiapas, Veracruz, 100-140 m)......... S. humilis (Miranda) G.E.Schatz 6. Petals 10-20 mm long; sepals 1.5-2 mm long; leaves and monocarps covered with minute, lens-like warts (Chiapas, 1,000-1,250 m)

\section{S. monticola Maas \& G.E.Schatz}

Stenanona migueliana Ortiz-Rodriguez \& G.E.Schatz, sp. nov. (Figures 1, 2).

Similar to $S$. stenopetala but differing in the flower pedicels and sepals longer, biseriate ovules and the surface of monocarps strongly tuberculate.

Type: MÉXICO: Chiapas: Zona sujeta a protección ecológica La Pera, municipio Berriozábal, carretera BerriozábalVistahermosa-El Cairo, antes de llegar a Trepatroncos, predio El Zapote. 16 51' 57.92" N, 93 19' 9.49” W, 1,100 m, 14 August 2011(fl), Ortíz-Rodríguez 0354 (holotype HEM; isotypes, MO, XAL).

Small tree, 3-10 m tall, young twigs and petioles densely covered with erect to apressed golden brown hairs. Leaves: petiole 4-9 mm long; lamina, shining, elliptic to broadly ellip- tic, 8-19 × 3-7 cm, membranaceous, strongly punctate with minute lens-like warts, upper side, glabrous, primary vein on upper side covered with erect hairs to glabrous, lower side sparsely covered with erect to appressed hairs, more dense on primary and secondary veins, base attenuate to acute, apex obtuse to acuminate, primary vein impressed on upper side and prominent on lower side, secondary veins $10-15$ on either side of primary vein. Inflorescences: on the branches or produced from the trunk, a condensed rhipidium bearing a single flower at a time; pedicels and outer side of bracts, sepals and petals densely covered with golden brown, erect to appressed hairs. Flowers: pendulous, peduncle 2-5 mm long; floral pedicels $20-40 \mathrm{~mm}$, bearing a triangular bract close to base, of c. $3 \mathrm{~mm}$ long; sepals 3, free, triangular, 3-6 by $3-5 \mathrm{~mm}$, apex acute; petals 6 , slightly involute, free, in 2 subequal whorls, cream (before anthesis) to pink (at anthesis), narrowly triangular to linear; outer petals $12-40$ by $3-7$ $\mathrm{mm}$; inner petals $17-50$ by $3-8 \mathrm{~mm}$; stamens c. $85,1.5-2.5$ $\mathrm{mm}$ long, apical part of connective compressed, ellipsoid to angulate, glabrous, truncate or projecting toward the gynoecium; carpels c. 11, 2-3 mm long, without style;ovary and stigma densely covered with golden brown hairs; stigma capitate, $0.3-0.8 \mathrm{~mm}$ long; ovules 8-11, biseriate. Monocarps: intense red with yellow mesocarp in vivo, yellowish green when young and brownish when dry, oblong to subglobose, $40-65 \times 26-35 \mathrm{~mm}$, strongly tuberculate and with minute lens-like warts, sparsely covered with appressed hairs, costate; fruiting pedicels to c. $70 \mathrm{~mm}$ long; stipes $3-5 \mathrm{~mm}$ long. Seeds: 3-10, ellipsoid to lenticular, 14-22 × 12-15 × 9-12 $\mathrm{mm}$, with peg-shaped (irregular) rumination.

Distribution and ecology: -Known only from two localities, Stenanona migueliana grows on a karstic zone at approximately 900-1,150 m above the sea level, in lower montane rain forest in the sense of Breedlove (1981) or "bosque tropical perennifolio" in the sense of Rzedowski (1978). Some common species in this forest are Quercus lancifolia Schltdl. \& Cham., Q. corrugata Hook., Calatola costaricensis Standl., Louteridium parayi Miranda, Justicia borrerae (Hemsl.) T.F.Daniel, Spathacanthus hahnianus Baill, and Bauhinia pansamalana Donn.Sm.

Interrelationships: -Stenanona migueliana most closely resembles S. stenopetala that also occurs in Chiapas. Differences between the two species are summarized as following: S. stenopetala has pedicels $9-23 \mathrm{~mm}$ long, sepals 2-3 $\mathrm{mm}$ long, ovules uniseriate, and the surface of monocarps smooth, minutely verrucose; whereas $S$. migueliana has pedicels 20-40 mm long, sepals 3-6 mm long, ovules biseriate, and the surface of monocarps strongly tuberculate. Monocarps of S. migueliana resemble those of S. tuberculata from Honduras in the tuberculate surface and distinct costa; however, S. tuberculata has flowers borne on very short pedicels, 2-5 $\mathrm{mm}$ long with longer sepals 6-15 mm long, whereas $S$. $m i$ gueliana has longer pedicels and shorter sepals.

Phenology: -Flowers have been collected and observed in 


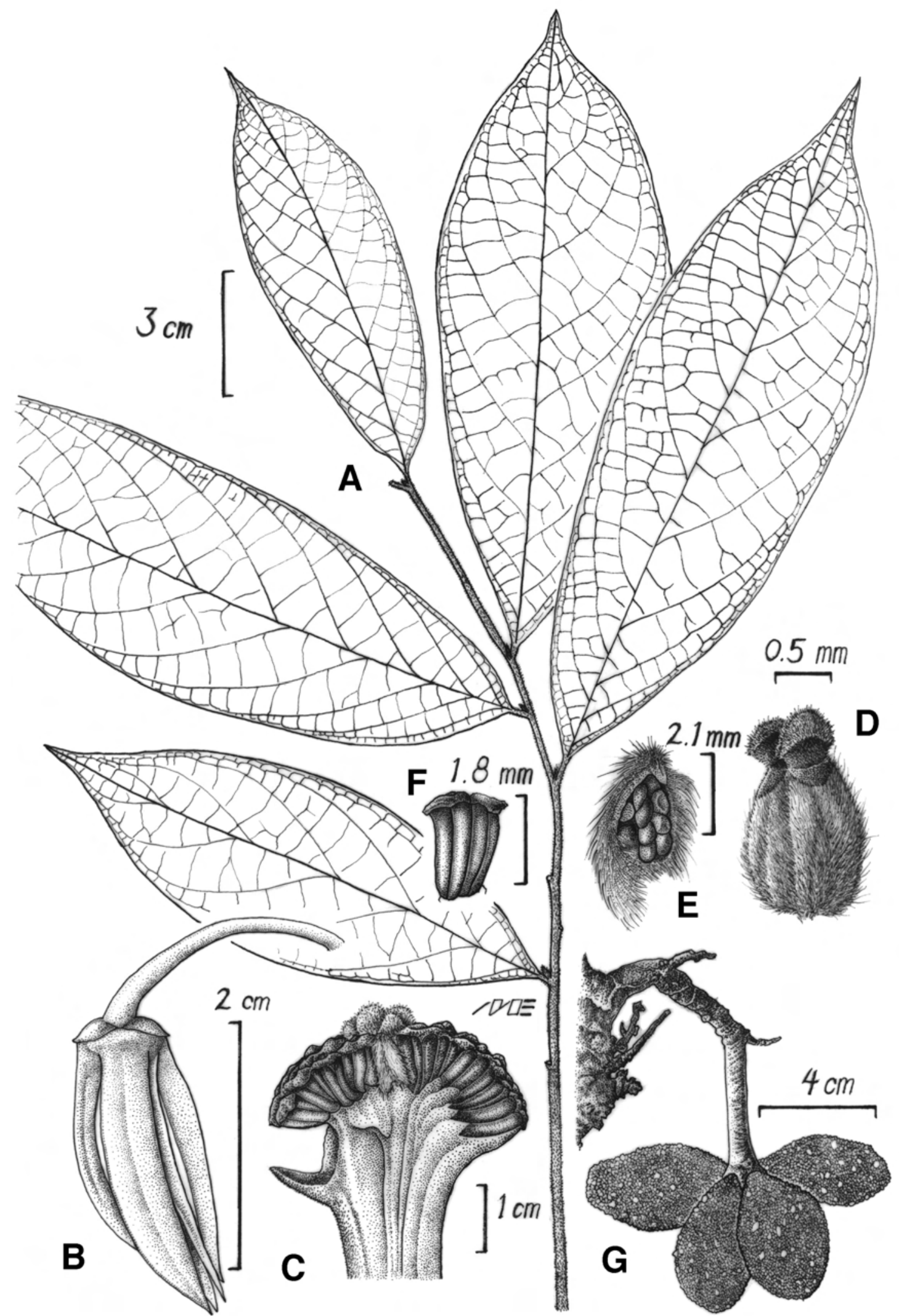

Figure 1. Stenanona migueliana Ortíz-Rodríguez \& G.E.Schatz. A. Leafy branch; B. Flower; C. Detail of androecium/gynoecium; D. Carpel; E. Detail of the arrangement of the ovules; F. Stamen; G. Rhipidium and monocarps. All illustrations were made based on specimens from the type locality. Draw by Manuel Escamilla 

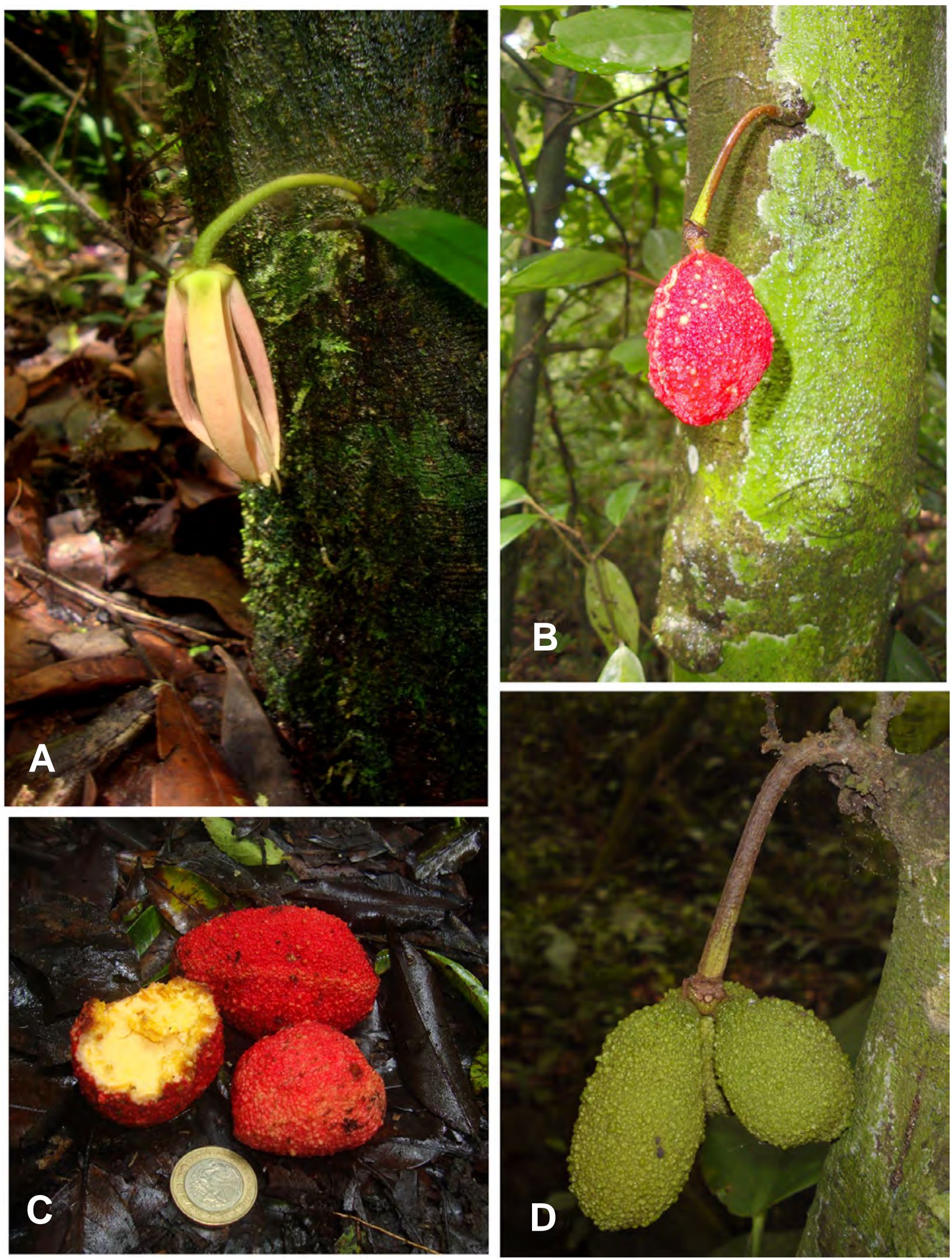

Figure 2. Stenanona migueliana Ortíz-Rodríguez \& G.E.Schatz. Photographs of the living plant. A. Flower; B. Mature fruits; C. Mature fruits with detail of yellow mesocarp; D. Immature fruit. Photographer: Andrés Ernesto Ortíz Rodríguez. 
the months of February (immature flower), July and August. The fruits have been observed and collected in July, August and September. Both structures have never been observed on the same plant.

Etymology: -The specific epithet honors Miguel Ángel Pérez Farrera, who has devoted much of his life to studying the flora of Chiapas, and in recent years has fought for the preservation of the La Pera ecological protection zone. Additional specimens examined: -CHIAPAS. Berriozábal: Zona sujeta a protección ecológica La Pera, municipio Berriozábal, carretera Berriozábal-Vistahermosa-El Cairo, antes de llegar a Trepatroncos, predio El Zapote. $16^{\circ} 51^{\prime}$ 57.92" N, 93 19' 9.49" W, 1,100 m, 01 August 2011(immature fr), Ortíz-Rodríguez 0360 (MO). Zona sujeta a protección ecológica La Pera, municipio Berriozábal, carretera Berriozábal-Vistahermosa-El Cairo, antes de llegar a Trepatroncos, predio Flor de café. $16^{\circ} 51^{\prime} 50.6^{\prime \prime} \mathrm{N}$ y $93^{\circ} 19^{\prime}$ 51.7" W, 900 m, 15 July 2011(fl), Licona-Vera 023 (XAL). Camino Berriozábal-Vista hermosa-El Cairo, Km 12 desvio al Pozo Turipache (La Pera). 16 51' 57.92"' N, 93 19' 9.49" W, 1,100 m, 8 September 2012 (fr), Ortíz-Rodríguez. 0405 (XAL). Ocozocuautla: rancho El Aguajito $30 \mathrm{~km}$ al NO de Ocozocuautla, 3 April 2002 (fl), E. Palacios E. 2768 (CHIP). $3 \mathrm{~km}$ del ejido Nuevo San Juan Chamula, Reserva de la Biosfera El Ocote. $16^{\circ} 56^{\prime} 13.6^{\prime \prime} \mathrm{N}, 93^{\circ} 32$ ' $50.5^{\prime \prime} \mathrm{W}$, 1,146 m, 15 July 2013 (fr), Josefa Anahí Espinosa Jiménez 1422 (HEM).

\section{Acknowledgements}

We wish to thank Christopher Davidson and Sharon Christoph for financing visits to the type locality; Andrew Vovides,
Lars Chatrou and Lubbert Westra for reviewing the manuscript and providing many useful comments. We are particularly grateful to Héctor Gómez Domínguez, Ana Celia Montes de Oca and friends of the Herbarium Eizi Matuda. Finally we thank Manuel Escamilla that provided the excellent illustration of S. migueliana.

\section{Literature cited}

Breedlove D.E. 1981. Flora of Chiapas, part I. Introduction to Flora of Chiapas. California Academy of Science, San Francisco.

Chatrou L.W., Pirie M.D., Erkens R.H.J., Couvreur T.L.P., Neubig K.M., Abbott J.R., Mols J.B., Maas J.W., Saunders R.M.K. and Chase M.W. 2012. A new subfamilial and tribal classification of the pantropical flowering plant family Annonaceae informed by molecular phylogenetics. Botanical Journal of the Linnean Society 169:5-40.

Couvreur T.L.P., Pirie M.D., Chatrou L.W., Saunders R.M.K., Su Y.C.F., Richardson J.E. and Erkens R.H.J. 2011. Early evolutionary history of the flowering plant family Annonaceae: steady diversification and boreotropical geodispersal. Journal of Biogeography 38:664-680.

Erkens R.H.J., Chatrou L.W. and Couvreur T.L.P. 2012. Radiations and key innovations in an early branching angiosperm lineage (Annonaceae; Magnoliales). Botanical Journal of the Linnean Society 169:117-134.

Pirie M.D. and Doyle J.A. 2012. Dating clades with fossils and molecules: the case of Annonaceae. Botanical Journal of the Linnean Society 169:84-116.

Rzedowski J. 1978. Vegetación de México. Limusa, México, D.F.

Schatz G.E. and Maas P.J.M. 2010. Synoptic revision of Stenanona (Annonaceae). Blumea 55:205-223.

Schatz G.E. 1987. Systematic and Ecological Studies in Central American Annonaceae. Doctoral Dissertation. University of Wisconsin. Madison. 503 pp. 